\title{
KEWAJIBAN NOTARIS MENGENALI PENGGUNA JASA DALAM UPAYA PENCEGAHAN TINDAK PIDANA PENCUCIAN UANG OLEH KORPORASI
}

\section{Ismail, Ermanto Fahamsyah, I Gede Widhiana Suarda}

Fakultas Hukum Universitas Jember Jawa Timur, Indonesia

Email: ismaildz10@gmail.com,ermanto.fahamsyah@gmail.com, igedewidhiana.suarda@unej.ac.id

\begin{abstract}
Abstrak
Prinsip mengenali Pengguna Jasa diterapkan dalam jabatan notaris dalam rangka melaksanakan ketentuan PP No 43 Tahun 2015 dan Permenkumham No 9 Tahun 2017, yang mana Notaris wajib menerapkan prinsip mengenali pengguna jasa. Prinsip Mengenali Pengguna Jasa bagi Notaris merupakan bagian dari upaya mendeteksi adanya penggunaan jasa notaris oleh para pelaku TPPU dengan melakukan identifikasi, verifikasi dan pemantauan identitas serta dokumen pada pengguna jasa Notaris. Tujuan dari penelitian ini yaitu untuk menemukan Menemukan kewajiban notaris mengenali pengguna jasa dalam upaya pencegahan tindak pidana pencucian uang oleh korporasi tidak bertentangan dengan Pasal 16 ayat (1) huruf f Undang-Undang Jabatan Notaris. Pada penelitian ini digunakan pendekatan yuridis normatif. Hasil dari penelitian ini yaitu Kewajiban notaris mengenali pengguna jasa dalam upaya pencegahan tindak pidana pencucian uang oleh korporasi tidak bertentangan dengan Pasal 16 ayat (1) huruf f Undang-Undang Republik Indonesian Nomor 2 Tahun 2014 tentang Perubahan atas Undang-Undang Nomor 30 Tahun 2004 tentang Jabatan Notaris
\end{abstract}

Kata Kunci: prinsip mengenali pengguna jasa; korposasi; tindak pidana pencucian uang

\section{Abstract}

The principle of recognizing service users is applied in the position of a notary in order to implement the provisions of PP No. 43 of 2015 and Permenkumham No. 9 of 2017, in which the notary is obliged to apply the principle of recognizing service users. The principle of recognizing service users for notaries is part of the effort to detect the use of notary services by money laundering offenses perpetrators by identifying, verifying and monitoring the identity and documents of notary service users. The purpose of this study is to find out that the obligation of a notary to recognize service users in an effort to prevent money laundering by corporations does not conflict with Article 16 paragraph (1) letter $f$ of the Law on Notary Positions. In this study, a normative juridical approach was used. The results of this study are that the obligation of a notary to recognize service users in an effort to prevent money laundering by corporations does not conflict with Article 16 paragraph (1) letter $f$ of the Law of the Republic of Indonesia Number 2 of 2014 concerning Amendments to Law Number 30 of 2004 concerning Notary position.

$\begin{array}{ll}\text { How to cite: } & \begin{array}{l}\text { Ismail. I., Fahamsyah. E., \& Suarda. I., G. W (2021) Kewajiban Notaris Mengenali Pengguna Jasa } \\ \text { dalam Upaya Pencegahan Tindak Pidana Pencucian Uang oleh Korporasi, Syntax Idea, 3(10), } \\ \text { https://doi.org/10.36418/syntax-idea.v3i10.1511 }\end{array} \\ \text { E-ISSN: } & \text { 2684-883X } \\ \text { Published by: } & \text { Ridwan Institute }\end{array}$


Ismail, Ermanto Fahamsyah, I Gede Widhiana Suarda

Keywords: the principle of recognizing service users; corporations; money laundering

\section{Received: 2021-09-22; Accepted: 2021-10-05; Published: 2021-10-20}

\section{Pendahuluan}

Pencucian uang adalah salah satu bentuk dari kejahatan kerah putih (white collar crimes) yang digunakan oleh pelaku tindak pidana yang ingin menyembunyikan keuntungan yang diperoleh melalui kegiatan melawan hukum. Pengedar narkoba dan pemasok barang palsu sering melakukan tindak pidana pencucian uang untuk menyembunyikan sumber pendapatan mereka (Adrian Sutedi, 2008). Money laundering yang merupakan bagian dari kejahatan terhadap pembangunan dan kesejahtraan sosial yang menjadi pusat perhatian dan keprihatinan dunia internasional terhadap kejahatan pencucian uang itu, tentunya sangat beralasan karena ruang lingkup dan dimensinya begitu luas sehingga kegiatannya mengandung ciri-ciri sebagai organized crime, whitecollar crime, corporate crime, dan transnational crime bahkan dengan kemajuan teknologi informasi money laundering dapat menjadi salah bentuk dari cyber crime (Adjie, 2008).

Dalam mendukung upaya pencegahan dan pemberantasan Tindak Pidana Pencucian Uang, pemerintah Indonesia bersama dengan Dewan Perwakilan Rakyat telah membentuk Undang-Undang Tindak Pidana Pencucian Uang Nomor 8 Tahun 2010 tentang Pencegahan dan Pemberantasan Tindak Pidana Pencucian Uang (selanjutnya disingkat dengan UU PPTPPU), Lembaran Negara Tahun 2010 Nomor 122, yang mencabut Undang-Undang Nomor 15 Tahun 2002 Tentang Tindak Pidana Pencucian Uang, dan Undang-Undang Nomor 25 Tahun 2003 Tentang Perubahan atas Undang-Undang Nomor 15 Tahun 2002 tentang Tindak Pidana Pencucian Uang. Salah satu terobosan hukum baru yang menarik dalam UU PPTPPU adalah adanya paradigma follow the money (mengikuti aliran uang). Follow the money merupakan paradigma baru dalam memberantas kejahatan atau pendekatan baru dalam memberantas TPPU. Pendekatan ini akan mempermudah dalam penegakan hukum bila dibandingkan dengan pendekatan konvensional yakni follow the suspect (menelusuri jejak pelaku) karena pelaku atau saksi bisa saja berkata bohong. Namun, jika aliran uang sudah diketahui maka pelaku atau saksi tidak akan bisa lagi untuk berbohong. Dengan menggunakan pendekatan follow the money, maka uang hasil kejahatan (proceed of crime) yang merupakan life of blood dari kejahatan. Pendekatan follow the money ini akan berjalan efektif jika didukung adanya pelaporan transaksi keuangan mencurigakan yang diberikan oleh pihak pelapor ke lembaga yang berwenang, dalam hal ini Pusat Pelaporan dan Analisis ransaksi Keuangan (selanjutnya disingkat dengan PPATK) (Poesoko, 2010).

Pemerintah beranggapan bahwa korporasi dapat dijadikan sarana baik langsung maupun tidak langsung oleh pelaku tindak pidana yang merupakan pemilik manfaat dari hasil tindak pidana pencucian uang dan pendanaan terorisme. Pemerintah memastikan upaya pencegahan dan pemberantasan tindak pidana tersebut telah mengikuti standar 
internasional. Salah satu bentuk keseriusan pemerintah dalam menangani tindak pidana pencucian uang adalah dengan membentuk PPATK. Selanjutnya, dalam Peraturan Menteri Hukum dan Hak Asasi Manusia Nomor 9 Tahun 2017 Tentang Penerapan Prinsip Mengenali Pengguna Jasa bagi Notaris (yang selanjutnya disebut Permenkumham No 9 Tahun 2017) dalam Pasal 2 ayat 1 notaris wajib menerapkan prinsip mengenali pengguna jasa, salah satu cara dalam penerapan prinsip pengguna jasa bagi notaris ialah pengumpulan informasi mengenai pengguna jasa orang perseorangan maupun korporasi, pengumpulan informasi mengenai pengguna jasa korporasi diatur didalam Permenkumham No 9 Tahun 2017 pasal 7 ayat (2) yang mana salah satunya mengetahui pemilik manfaat (Beneficial Owner) dari korporasi tersebut.

Prinsip mengenali Pengguna Jasa diterapkan dalam jabatan notaris dalam rangka melaksanakan ketentuan PP No 43 Tahun 2015 dan Permenkumham No 9 Tahun 2017, yang mana Notaris wajib menerapkan prinsip mengenali pengguna jasa. Prinsip Mengenali Pengguna Jasa bagi Notaris merupakan bagian dari upaya mendeteksi adanya penggunaan jasa notaris oleh para pelaku TPPU dengan melakukan identifikasi, verifikasi dan pemantauan identitas serta dokumen pada pengguna jasa Notaris. akan tetapi Notaris terkendala confidentiality of client yaitu menjaga kerahasiaan segala sesuatu mengenai aktanya. Sebagaimana tercantum dalam Pasal 16 ayat (1) huruf $\mathrm{f}$ Undang-Undang Republik Indonesian Nomor 2 Tahun 2014 tentang Perubahan atas Undang-Undang Nomor 30 Tahun 2004 tentang Jabatan Notaris (yang selanjutnya disebut dengan UUJN) yang menyatakan bahwa dalam menjalankan jabatannya, Notaris wajib merahasiakan segala sesuatu mengenai Akta yang dibuatnya dan segala keterangan yang diperolah guna pembuatan Akta sesuai dengan sumpah/janji jabatan, kecuali undang-undang menentukan lain. Berdasarkan penjelasan pasal tersebut, kewajiban untuk merahasiakan segala sesuatu yang berhubungan dengan akta dan suratsurat lainnya adalah untuk melindungi kepentingan sesama pihak yang terkait dengan akta tersebut.

Berdasarkan beberapa peraturan perundang-undangan yang ada mengenai Penerapan prinsip mengenali pengguna jasa bagi notaris terdapat beberapa ketidakpastian penerapan hukum. Dimana Notaris terkendala confidentiality of client yaitu menjaga kerahasiaan segala sesuatu mengenai aktanya. Hal tersebut menimbulkan ketidakpastian hukum, sehingga yang menjadi rumusan masalah dalam penelitian ini adalah apakah kewajiban notaris mengenali pengguna jasa dalam upaya pencegahan tindak pidana pencucian uang oleh korporasi tidak bertentangan dengan Pasal 16 ayat (1) huruf f Undang-Undang Jabatan Notaris.

\section{Metode Penelitian}

\section{a. Tipe Penelitian}

Tipe penelitian yang digunakan dalam penulisan tesis ini adalah Tipe penelitian Yuridis Normatif, dimana dalam penelitian ini menitik beratkan logika keilmuan hukum dari sisi normatifnya yang memiliki sebuah arti yaitu permasalahan yang diangkat, dibahas dan diuraikan pada sebuah penelitan yang fokus dengan 
menerapkan kaidah-kaidah dengan mengkaji aturan-aturan hukum yang sifatnya formal seperti Undang-Undang, yang dalam literatur-literaturnya sifatnya teoritis kemudian dihubungkan dengan permasalahan yang menjadi pokok pembahasan (Ibrahim, 2006).

\section{b. Pendekatan Masalah}

Terdapat beberapa macam dalam pendeketan penelitian hukum. Dengan adanya pendekatan tersebut penulis mendapatkan suatu informasi dari berbagai aspek yang berkaitan dengan isu hukum dalam permasalahan yang akan diangkat dan kemudian dicari jawabannya. Adapun dalam penyusunan tesis ini, penulis menggunakan 3 (tiga) macam pendekatan, yaitu:

\section{Pendekatan Perundang-undangan (Statute Approach)}

Pendekatan Undang-undang dilakukan dengan cara menelaah semua undang-undang dan juga regulasi yang berkaitan dengan isu hukum yang dihadapi (Sari et al., 2020). Penulis melakukan penafsiran autentik terhadap segala sesuatu yang ada pada permasalahan hukum yang dihadapi. Dalam pendekatan undangundang ini dapat membuka kesempatan bagi penulis untuk mempelajari adakah konsistensiden kesesuaian antara undang-undang satu dengan undang-undang yang lain ataupun antara undang-undang dan Undang-undang Dasar antara regulasi undang-undang, maka dengan adanyapendekatan ini penulis akan mengkaji konsistensi undang-undang dan juga regulasi yang ada hubungannya dengan permasalahan hukum.

Dengan melakukan pendekatan perundang-undangan, penulis telah menemukan adanya ketidaksesuaian peraturan yaitu pada Pasal 4 dan Pasal 16 Undang-undang Jabatan Notaris dengan Peraturan Hukum dan Hak Asasi Manusia Nomor 9 Tahun 2017. Hasil telaah tersebut merupakan sebuah argument untuk memecahkan isu hukum yang dihadapi (M A Amrullah \& Korporasi, 2018).

\section{Pendekatan Konseptual (conceptual approach)}

Pendekatan konseptual ini beranjak dari pandangan-pandangan maupun doktrin-doktrin yang berkembang dalam ilmu hukum. Dengan ini penulis memperlajari tentang pandangan-pandangan dan doktrin-doktrin dalam ilmu hukum, yang akan menemukan ide-ide yang melahirkan pengertian-pengertian hukum, konsep-konsep hukum dan asas-asas hukum yang relevan dengan isu hukum yang dihadapi (M Arief Amrullah, 2020). Pendekatan konsep dalam penelitian ini digunakan untuk memahami konsep money laundering dan juga pihak pelapor yang bertujuan agar dalam penormaan aturan hukum tidak lagi memungkinkan ada pemahaman yang ambigu dan juga kabur.

\section{Pendekatan Historis (Histories Approach)}

Pendekatan historis dilakukan dengan meneliti latar belakang yaitu terbentunya Undang-undang PPTPPU dengan Permenkumham Nomor 9 Tahun 2017 tentang Penerapan Prinsip Mengenali Pengguna Jasa Bagi Notaris. Penelitian ini dilakukan oleh peneliti untuk mengungkap sejarah sebelum lahirnya Penerapan Prinsip Mengenali Pengguna Jasa Bagi Notaris yang diatur oleh 
Permenkumham Nomor 9 Tahun 2017. Pendekatan historis ini diperlukan jika memang peneliti menganggap bahwa pengungkapan sejarah, filosofis dan pola pikir menjadi sesuatu yang dipelajari untuk dilahirkan kembali, dan memang mempunyai relevansi kedepan dengan masa kini.

\section{Hasil dan Pembahasan}

\section{Sejarah Undang-Undang Tindak Pidana Pencucian Uang di Indonesia}

Indonesia pada tahun 1997 telah meratifikasi United Nation Convention Against Illucit Traffic in Narcotic Drugs and Psychotropic Substances 1998 (Konvensi 1998). Konsekuensi ratifikasi tersebut, Indonesia harus segera membuat aturan untuk pelaksanaanya. Pada tahun 2001 Indonesia bersama 17 negara lainnya diancam sanksi internasional. Undang-undang Nomor 15 tahun 2002 tentang Tindak Pidana Pencucian Uang disahkan pada Tanggal 17 April 2002 yang dimana merupakan hari yang bersejarah dalam dunia hukum Indonesia. Kenyataannya meskipun sudah ada Undang-undang Nomor 15 Tahun 2002 tentang Tindak Pidana Pencucian Uang penerapannya kurang, sehingga akhirnya Indonesia masuk daftar hitam negara yang tidak kooperatif. Bahkan Indonesia dicurigai sebagai surga bagi pencucian uang, karena menganut sistem devisa bebas, rahasia bank yang ketat, korupsi yang merajalela, maraknya kejahatan narkotik, dan tambahan lagi pada saat itu perekonomian Indonesia dalam keadaan yang tidak baik, sehingga ada kecenderungan akan menerima dana dari mana pun untuk keperluan pemulihan ekonomi (Yanuarsari, 2018).

Tanggal 13 Oktober 2003 diubah dengan Undang-Undang Nomor 25 Tahun 2003 Tentang Perubahan atas Undang-undang Nomor 15 tahun 2002 Tentang Tindak Pidana Pencucian Uang. Undang-undang tersebut merupakan desakan internasional terhadap Indonesia antara lain dari Financial Action Task Force (FATF), badan internasional di luar PBB. Anggotanya terdiri dari negara donor dan fungsinya sebagai satuan tugas dalam pemberantasan pencucian uang. Pada 23 Oktober 2003, Financial Action Task Force (FATF) di Stockholm, Swedia, menyatakan Indonesia, Cook Islands, Mesir, Guatemala, Myanmar, Nauru, Nigeria, Filipina dan Ukraina sebagai negara yang tidak kooperatif dalam pemberantasan pencucian uang (Yanuarsari, 2018). Keberadaan Indonesia berada pada daftar Non Cooperative Countries and Territories sesuai dengan rekomendasi (NCCT's) dari Financial Actions Task Force on Money Laundering. Bahwa setiap transaksi dengan perorangan maupun badan hukum yang berasal dari negara $\mathrm{NCCT}^{\text {ee }}$ s harus dilakukan dengan penelitian seksama. Berbagai upaya selama beberapa tahun, antara Iain dengan mengesahkan UU No. 25 Tahun 2003 Tentang Perubahan Atas UU No. 15 Tahun 2002 Tentang Tindak Pidana Pencucian Uang, mendirikan PPATK, mengeluarkan ketentuan pelaksanaan dan mengadakan kerja sama internasional, akhirnya membuahkan hasil. Februari 2006 Indonesia dikeluarkan dari daftar $\mathrm{NCCT}^{\mathrm{ee}} \mathrm{s}$ setelah dilakukan formal monitoring selama satu tahun (Yanuarsari, 2018). 
Beberapa tahun kemudian, tepatnya di tahun 2010, DPR bersama Presiden menyepakati Undang-Undang Nomor 8 Tahun 2010 Tentang Pencegahan dan Pemberantasan Tindak Pidana Pencucian Uang. Adanya Undang-Undang ini, bertujuan agar tindak pidana pencucian uang dapat dicegah dan diberantas. Secara internasional, Financial Action Task Force (FATF) on Money Laundering telah mengeluarkan standar internasional bagi setiap negara dalam pencegahan dan pemberantasan TPPU dan TPPT, salah satunya yaitu transparansi kepemilikan manfaat dari badan usaha.

Dalam mendukung pelaksanaan ketentuan Pasal 17 ayat (2) Undang-Undang Nomor 8 Tahun 2010 tentang Pencegahan dan Pemberantasan Tindak Pidana Pencucian Uang, perlu menetapkan Peraturan Pemerintah tentang Pihak Pelapor dalam Pencegahan dan Pemberantasan Tindak Pidana Pencucian Uang; pencegahan dan pemberantasan tindak pidana pencucian uang. Sehingga Pemerintah bersama Dewan Perwakilan Rakyat membentuk Peraturan Pemerinta Republik Indonesia Nomor 43 Tahun 2015 Tentang Pihak Pelapor Dalam Pencegahan dan Pemberantasan Tindak Pidana Pencucian Uang yang di Undangkan di Jakarta tanggal 23 Juni 2015. Adapun substansi yang diatur dalam Peraturan Pemerintah ini yakni:

1. Menambah jenis penyedia jasa keuangan yang terdiri atas perusahaan modal ventura, perusahaan pembiayaan infrastruktur, lembaga keuangan mikro, dan lembaga pembiayaan ekspor sebagai Pihak Pelapor;

2. Menyatakan advokat, notaris, pejabat pembuat akta tanah, akuntan, akuntan publik, dan perencana keuangan sebagai Pihak Pelapor.

Penambahan jenis penyedia jasa keuangan yang terdiri atas perusahaan modal ventura, perusahaan pembiayaan infrastruktur, lembaga keuangan mikro, dan lembaga pembiayaan ekspor sebagai Pihak Pelapor dilatarbelakangi oleh aktivitas bisnis atau usaha yang dilakukan oleh perusahaan atau lembaga tersebut rentan untuk dijadikan sarana dan sasaran tindak pidana pencucian uang.

Bagi advokat, notaris, pejabat pembuat akta tanah, akuntan, akuntan publik, dan perencana keuangan, berdasarkan hasil riset PPATK rentan dimanfaatkan oleh pelaku tindak pidana pencucian uang untuk menyembunyikan atau menyamarkan asal usul Harta Kekayaan yang merupakan hasil dari tindak pidana dengan cara berlindung dibalik ketentuan kerahasiaan hubungan profesi dengan Pengguna Jasa yang diatur sesuai dengan ketentuan peraturan perundang-undangan. Hal ini sejalan dengan rekomendasi yang dikeluarkan oleh Financial Action Task Force (FATF) yang menyatakan bahwa terhadap profesi tertentu yang melakukan Transaksi Keuangan Mencurigakan untuk kepentingan atau untuk dan atas nama Pengguna Jasa wajib melaporkan Transaksi tersebut kepada Financial Intelligence Unit (dalam hal ini adalah PPATK) (Peraturan Pemerintah Republik Indonesia, 2015).

Kewajiban pelaporan oleh profesi tesebut telah diterapkan di banyak negara dan memiliki dampak positif terhadap pencegahan dan pemberantasan tindak pidana pencucian uang. Selain itu, pengaturan Pihak Pelapor dan pelaksanaan kewajiban pelaporan oleh perusahaan modal ventura, perusahaan pembiayaan infrastruktur, 
lembaga keuangan mikro, lembaga pembiayaan ekspor, advokat, notaris, pejabat pembuat akta tanah, akuntan, akuntan publik, dan perencana keuangan dimaksudkan untuk melindungi Pihak Pelapor tersebut dari tuntutan hukum, baik secara perdata maupun pidana.

Bahwa untuk melaksanakan ketentuan Pasal 6 ayat (1) Peraturan Pemerintah Nomor 43 Tahun 2015 tentang Pihak Pelapor dalam Pencegahan dan Pemberantasan Tindak Pidana Pencucian Uang ditetapkan Peraturan Menteri Hukum dan Hak Asasi Manusia Republik Indonesia Nomor 9 Tahun 2017 Tentang Penerapan Prinsip Mengenali Pengguna Jasa Bagi Notaris yang diundangkan pada tanggal 4 Agustus 2017.

Merespon hal ini, Presiden Indonesia telah mengeluarkan Perpres Nomor 13 Tahun 2018 Tentang Penerapan Prinsip Mengenali Pemilik Manfaat dari Korporasi dalam Rangka Pencegahan dan Pemberantasan TPPU dan TPPT. Kemenkumham dalam kolaborasi dengan Pusat Pelaporan dan Analisis Transaksi Keuangan (PPATK) mengundangkan peraturan turunan dari Perpres Nomor 13 Tahun 2018 tersebut, yakni Permenkumham Nomor 15 Tahun 2019 tentang Tata Cara Pelaksanaan Penerapan Prinsip Mengenali Pemilik Manfaat dari Korporasi (Selanjutnya disebut Permenkumham No 15 Tahun 2019) dan Permenkumham Nomor 21 Tahun 2019 tentang Tata Cara Pengawasan Penerapan Prinsip Mengenali Pemilik Manfaat dari Korporasi (Selanjutnya disebut Permenkumham No 21 Tahun 2019). Permenkumham Nomor 15 Tahun 2019 menjadi acuan bagi korporasi untuk mengidentifikasi siapa saja pemilik manfaat yang terdapat dalam korporasinya, serta bagaimana korporasi tersebut dapat menyampaikan informasi tentang data pemilik manfaat kepada instansi berwenang, dalam hal ini adalah Kemenkumham. Sementara itu, Permenkumham Nomor 21 Tahun 2019 bertujuan memastikan penerapan prinsip mengenali pemilik manfaat telah dilaksanakan sesuai peraturan perundangundangan. Transparansi pemilik manfaat korporasi berkaitan erat dengan investasi di Indonesia. Kepercayaan investor luar negeri kepada Indonesia sangat bergantung pada ketersediaan data yang akurat, terkini dan transparan terkait pemilik manfaat atas korporasi.

\section{Kewajiban Notaris Mengenali Pengguna Jasa dalam Pencegahan Tindak Pidana Pencucian Uang oleh Korporasi}

Munculnya istilah pencucian uang (money laundering) dikenal sejak tahun 1930 di Amerika Serikat, erat kaitannya dengan perusahaan pencucian pakaian (laundry) dan perusahaan ini dibeli olah para mafia dengan dana yang mereka peroleh dari hasil kejahatannya. Perusahaan ini digunakan dengan sah dan resmi sebagai salah satu strateginya yang merupakan investasi terbesarnya. Berbagai perolehan uang hasil kejahatan seperti dari cabang usaha lainnya ditanamkan ke perusahaan pencucian pakaian ini, seperti uang hasil minuman keras ilegal, hasil perjudian, dan hasil usaha pelacuran. Perusahaan ini mereka gunakan untuk menyembunyikan uang yang mereka hasilkan dari hasil kejahatan dan transaksi illegal sehingga tampak seolah-olah berasal dari sumber yang halal dan sah. 
Berkembangnya pelaksanaan kejahatan pencucian uang semakin maju dengan memanfaatkan kemajuan teknologi dan zaman membuat kejahatan ini semakin sulit untuk dicegah dan dibuktikan. Bahkan kejahatan pencucian uang bukan hanya dalam skala nasional tetapi juga dalam skala regional dan global, dimana kejahatan ini dilakukan oleh berbagai kelompok, kalangan dan juga organisasi internasional (International Organitation). Kejatahan pencucian uang dianggap sebagai suatu fenomena kejahatan yang menyangkut terutama dunia kejahatan yang disebut "Organized Crime" karena dimensi dan implikasinya yang melanggar batas-batas Negara.

Awalnya kejahatan pencucian uang ini dianggap sangat erat hubungannya dengan perdagangan obat bius/narkotika dan kejahatan lainnya, namun dalam perkembangannya, hasil atau proses dari kejahatan ini sudah dihubungkan dengan tindak kriminal secara umum dalam jumlah yang besar, seperti korupsi. Hal ini disebabkan karena hasil harta/kekayaan yang dihasilkan dalam jumlah besar dengan cara disembunyikan yang disebut dengan uang kotor (dirty money).

Menurut Sarah N. Welling Uang dapat menjadi kotor dengan dua cara, yaitu:

1. Pertama melalui pengelakan pajak (tax evasion), yaitu memperoleh uang secara legal, tetapi jumlah yang dilaporkan kepada pemerintah untuk keperluan perhitungan pajak lebih sedikit daripada yang sebenarnya diperoleh.

2. Memperoleh uang melalui cara-cara yang melanggar hukum. Teknik-teknik yang biasa dilakukan untuk hal itu, antara lain penjualan obat-obatan terlarang atau perdagangan narkoba secara gelap (drug sales atau drug trafficking), penyuapan (bribery), terorisme (terrorism), pelacuran (prostitution), perdagangan senjata (arms trafficking), penyelundupan minuman keras, tembakau, dan pornografi (smuggling of contraband alcohol, tobacco, pornography), penyelundupan imigran gelap (illegal immigration rackets atau people smuggling), dan kejahatan kerah putih (white collar crime).

Modus operandi tindak pidana pencucian uang secara operasional dilakukan dengan cara jual beli barang dan jasa (konversi jual beli), pengalihan usaha di negara tertentu seperti negara yang memiliki prosedur bisnis yang mudah, pajak yang ringan dan longgar serta ketentuan rahasia bank yang sangat ketat sehingga dapat menyimpan uang di bank atau lembaga keuangan di daerah (offshore konversi), dan praktek bisnis yang sah sebagai sarana untuk mentransfer dan memanfaatkan hasil kejahatan yang dikonversi melalui transfer, cek atau alat pembayaran lainnya yang kemudian disimpan di rekening bank atau ditarik atau ditransfer kembali ke rekening bank lain (percakapan bisnis yang sah). Cara ini dapat memungkinkan pelaku tindak pidana untuk menjalankan usaha atau bekerjasama dengan mitra usahanya dan menggunakan rekening perusahaan sebagai tempat menyimpan uang hasil tindak pidana yang dilakukan.

Cara pemutihan uang atau hasil dari kejahatan pencucian uang (money laundering), yaitu dilakukan melalui serangkaian transaksi financial yang di buat rumit guna untuk menyulitkan pembuktian untuk mengetahui asal-usul suatu 
dana/uang tersebut dari berbagai pihak. Para pelaku pencucian uang memanfaatkan kerahasiaan bank atau perusahaan keuangan lainnya yang umumnya dijunjung tinggi oleh perbankan untuk menyimpan harta/kekayaan dari kejahatan tersebut. Adanya globalisasi perbankan, dana hasil kejahatan mengalir/bergerak melampaui batas yurisdiksi negara. Melalui mekanisme ini, akan sulit untuk menanggulangi/menggagalkan kehajatan pencucian uang yang bergerak dari suatu negara ke negara lain bahkan ke negara yang menerapkan ketentuan kerahasiaan bank secara ketat karena belum mempunyai sistem hukum yang kuat. UU PPTPPU mengkategorikan sejumlah tindak pidana yang sejenis dengan pengaturan predicate crime dalam FATF. Sejumlah tindak pidana yang termasuk predicate crime dalam tindak pidana pencucian uang diatur dalam Pasal 2 ayat 1 UU PPTPPU.

Subjek tindak pidana pencucian uang dapat dilihat dari ketentuan-ketentuan yang terdapat dalam UU PPTPPU, yaitu orang perseorangan dan korporasi. Setiap orang yang berada di dalam atau di luar wilayah Negara Kesatuan Republik Indonesia yang turut serta melakukan percobaan, pembantuan untuk melakukan tindak pidana pencucian uang dipidana dengan pidana yang sama seperti dalam Pasal 3, Pasal 4, dan Pasal 5 UU PPTPPU. Formulasi setiap orang disini disebutkan dalam Pasal 1 angka 9 UUPPTPPU yang menyatakan: "Setiap Orang adalah orang perseorangan atau Korporasi”.

Ketentuan di Pasal 5 ayat (1) UU PPTPPU dikecualikan bagi pihak pelapor yang melaksanakan kewajiban pelaporan. Untuk delik tindak pidana pencucian uang seperti dalam Pasal 3, Pasal 4, dan Pasal 5 UU PPTPPU dilakukan oleh korporasi, maka pidana dijatuhkan terhadap korporasi dan/atau personil pengendali korporasi. Sementara itu, mengenai pihak-pihak yang dapat dimintai pertanggungjawaban pidana dalam hal terjadi kejahatan korporasi (corporate crime) ialah sebagaimana dirumuskan dalam ketentuan Pasal 6 ayat (2) UU PPTPPU, yaitu:

(2) Pidana dijatuhkan terhadap Korporasi apabila tindak pidana Pencucian Uang:

a. dilakukan atau diperintahkan oleh Personil Pengendali Korporasi;

b. dilakukan dalam rangka pemenuhan maksud dan tujuan Korporasi;

c. dilakukan sesuai dengan tugas dan fungsi pelaku atau pemberi perintah; dan

e. dilakukan dengan maksud memberikan manfaat bagi Korporasi.

Pasal 9 UU PPTPPU dijelaskan tentang pidana pengganti apabila korporasi yang tidak mampu membayar pidana denda maka diganti dengan perampasan harta korporasi atau personil pengendali korporasi yang nilainya sama dengan putusan pidana denda yang dijatuhkan. Selain itu, apabila penjualan harta korporasi yang dirampas tidak mencukupi, pidana kurungan pengganti denda dijatuhkan terhadap personil pengendali korporasi dengan memperhitungkan denda yang telah dibayar.

Korporasi merupakan badan usaha yang keberadaannya dan status hukumnya disamakan seperti manusia (orang), tanpa melihat bentuk organisasinya. Korporasi dapat memiliki kekayaan dan utang, mempunyai kewajiban dan hak dan dapat bertindak menurut hukum, melakukan gugatan dan dapat dituntut di pengadilan. Sehingga, dapat dikatakan bahwa korporasi layaknya seperti manusia yang memiliki fisik dan organ 
dalam melaksanakan aktivitasnya. Hal ini juga menegaskan bahwa korporasi dapat dimintai pertanggungjawabannya bila melakukan tindak pidana (Nasution, 2015). Sulitnya membuktikan dan mengidentifikasi keterlibatan pengurus korporasi yang bertindak atas nama sendiri maupun bertindak atas nama korporasi menjadi salah satu kendala pemberantasan tindak pidana pencucian uang yang dilakukan korporasi. Mengambil pembelajaran dari berbagai kasus yang terjadi di negeri ini terkait dengan tindak pidana pencucian uang yang ternyata melibatkan korporasi sebagai media kejahatan, maka sangat perlu untuk memperjelas isi dari undang-undang pencucian uang.

Dewasa ini semakin banyaknya Tindak Pidana Pencucian Uang yang baik yang dilakukan oleh orang ataupun korporasi yang menyebabkan kerugian bagi negara, oleh sebab itu dibutuhkan Pihak yang memiliki tanggung jawab untuk melaporkan Tindak Pidana Pencucian Uang. Oleh karena itu UU PPTPPU telah menetapkan kategori Pihak Pelapor sebagaimana tercantum pada Pasal 17 ayat (1) huruf a dan huruf b yang terdiri dari Penyedia Jasa Keuangan (PJK) dan Penyedia Barang dan/atau Jasa Lain (PBJ). Selanjutnya sebagaimana amanat Pasal 17 ayat (2) UU PPTPPU, Profesi ditetapkan menjadi Pihak Pelapor sebagaimana terdapat dalam Pasal 3 Peraturan Pemerintah Republik Indonesia Nomor 43 Tahun 2015 Tentang Pihak Pelapor Dalam Pencegahan dan Pemberantasan Tindak Pidana Pencucian Uang (Selanjutnya disebut PP Nomor 43 Tahun 2015). Berdasarkan pasal tersebut diatas Notaris termasuk salah satu profesi yang memiliki kewajiban melaporkan segala Tindak Pidana Pencucian Uang. Kewajiban untuk menerapkan program anti pencucian uang dan pendanaan terorisme yaitu:

1. Penerapan Prinsip Mengenali Pengguna Jasa (PMPJ);

2. Penyampaian Laporan Transaksi Keuangan Mencurigakan (LTKM) kepada PPATK.

Prinsip Mengenali Pengguna Jasa adalah prinsip yang diterapkan oleh Pihak Pelapor untuk mengetahui latar belakang dan identitas Pengguna Jasa, memantau transaksi, serta melaporkan transaksi kepada otoritas berwenang Pusat Pelaporan dan Analisa Transaksi Keuangan yang selanjutnya disebut dengan PPATK. Prinsip Mengenali Pengguna Jasa merupakan salah satu cara memitigasi resiko nasional atas dinamika nasional, regional maupun global yang diiringi dengan perkembangan produk, aktivitas dan teknologi informasi, meningkatkan peluang penyalanggunaan fasilitas dan produk dari industri keuangan dan lembaga yang terkait dengan keuangan, oleh pelaku kejahatan terutama sebagai sarana pencucian uang (Permatasari, 2017). Habib Adjie menyatakan bahwa kewenangan umum ini memiliki batasan yaitu (Permatasari, 2017):

1. Tidak dikecualikan kepada pejabat yang ditetapkan undang-undang.

2. Menyangkut akta yang harus dibuat atau berwenang membuat akta otentik mengenai semua perbuatan, perjanjian dan ketetapan yang diharuskan oleh aturan hukum atau dikehendaki oleh yang bersangkutan.

3. Mengenai subjek hukum (orang atau badan hukum) untuk kepentingan siapa akta itu dibuat atau dikehendaki oleh yang berkepentingan.

Terkait dengan kewenangan seorang notaris dalam melaksanakan jabatannya sesuai dengan ketentuan undang-undang maka berlaku Pasal 50 KUHP yang 
memberikan perlindungan bagi notaris yang telah melaksanakan tugas jabatannya sesuai dengan ketentuan undang-undang, yaitu: "Tidaklah dapat dihukum, barangsiapa melalukan sesuatu perbuatan untuk melaksanakan suatu peraturan perundangundangan."

Kewenangan khusus Notaris dituangkan dalam Pasal 15 ayat (2) yang dimana Notaris berwenang mengesahkan tanda tangan dan menetapkan kepastian tanggal surat di bawah tangan dengan mendaftar dalam buku khusus, membukukan surat-surat di bawah tangan dengan mendaftar dalam buku khusus, membuat kopi dari asli surat-surat di bawah tangan berupa salinan yang memuat uraian sebagaimana ditulis dan digambarkan dalam surat yang bersangkutan, melakukan pengesahan kecocokan fotokopi dengan surat aslinya, memberikan penyuluhan hukum sehubungan dengan pembuatan akta, membuat akta yang berkaitan dengan pertanahan dan membuat akta risalah lelang. Pasal 15 ayat (3) menjelaskan, selain kewenangan notaris yang sudah disebutkan, notaris mempunyai kewenangan lainnya yang terdapat dalam peraturan perundang-undangan, yaitu Kewenangan mensertifikasi transaksi yang dilakukan secara elektronik (cyber notary), Membuat Akta ikrar wakaf, dan Hipotek pesawat terbang.

Kewajiban Notaris dalam menerapkan prinsip mengenali Pengguna Jasa merupakan bagian terpenting dalam rangka pencegahan dan pemberantasan tindak pidana pencucian uang yang wajib diterapkan oleh pihak pelapor. Berdasarkan PP Nomor 43 Tahun 2015 termuat dalam ketentuan Pasal 8 Ayat (1) Pihak pelapor wajib menyampaikan laporan transaksi keuangan mencurigakan kepada PPATK untuk kepentingan atau untuk dan atas nama Pengguna Jasa. Namun, dalam pelaksanan tugas jabatan Notaris sebagai Pejabat Umum berdasarkan ketentuan pasal 4 ayat (2) Jo. Pasal 16 ayat (1) huruf $\mathrm{f}$ dari UUJN dapat disimpulkan rumusan hukum yang bersifat imperatif tentang kewajiban yang melekat dalam tugas jabatannya sebagai Notaris dalam rangka merahasiakan isi akta dan keterangan-keterangan yang diperolehnya dalam pembuatan akta, terkecuali Undang-undang menentukan lain.

Dalam ketentuan UUJN dinyatakan Notaris merupakan pejabat umum yang berwenang untuk membuat akta otentik, yang memiliki fungsi sebagai alat bukti untuk menciptakan kepastian dan perlindungan hukum bagi masyarakat. Notaris memiliki peran untuk membantu menciptakan kepastian dan perlindungan hukum bagi masyarakat dengan menerbitkan pembuktian berupa akta autentik. Notaris dalam melaksanakan kegiatan profesi diatur oleh Undang-undang Peraturan Jabatan Notaris yang dikenal dengan Undang-Undang Jabatan Notaris Nomor 2 tahun 2014 tentang Perubahan atas Undang-undang Nomor 30 Tahun 2004 Tentang Jabatan Notaris. Terkait dengan pengaturan isi akta diatur di dalam Pasal 4 ayat (2) jo Pasal 16 ayat (1) huruf f yang menyatakan bahwa dalam menjalankan jabatannya, Notaris berkewajiban merahasiakan segala sesuatu mengenai akta yang dibuatnya dan segala keterangan yang diperoleh guna pembuatan akta sesuai dengan sumpah atau janji jabatan, kecuali undang-undang menentukan lain (Undang-undang Jabatan Notaris No 2 tahun 2014, 2014). Hal ini merupakan wujud dari jabatan kepercayaan dari masyarakat dalam lalu 
lintas hukum perdata yaitu untuk merahasiakan mengenai segala sesuatu akta yang dibuatnya (Tarigan, 2021).

Kewajiban seorang notaris diatur di dalam Pasal 16 dan Pasal 16 A Undangundang Jabatan Notaris Nomor 30 Tahun 2004 yang dirubah dengan Undang-undang Nomor 2 Tahun 2014. Terkait dengan kewajiban seorang notaris yang utama adalah merahasiakan aktanya serta seluruh pembicaraan pada tahap pra pembuatan akta yaitu persiapan pembuatan akta (Kohar, 1983). Kewajiban notaris diatur didalam Pasal 16 ayat (1) huruf a sampai dengan huruf $n$ UUJN

Bila kewajiban tersebut dilanggar seorang notaris dapat dikenakan sanksi seperti yang diatur didalam Pasal 84 dan Pasal 85 UUJN, yaitu: Tindakan pelanggaran notaris yang mengakibatkan suatu akta hanya mempunyai kekuatan pembuktian sebagai akta di bawah tangan atau suatu akta menjadi batal demi hukum dapat menjadi alasan bagi pihak yang menderita kerugian untuk menuntut penggantian biaya, ganti rugi, dan bunga kepada Notaris dan juga sanksi dapat berupa teguran lisan, teguran tertulis, pemberhentian sementara, pemberhentian dengan hormat atau pemberhentian dengan tidak hormat.

Sebelum menjalankan jabatannya, Notaris wajib mengucapkan sumpah/janji menurut agamanya di hadapan Menteri atau pejabat yang ditunjuk. Adapun sumpah/janji Kemudian, setelah Notaris mengucapkan sumpah janji sesuai dengan agama atau kepercayaanya masing-masing di hadapan Menteri atau Pejabat yang ditunjuk melaksanakan jabatan dengan amanah, jujur, saksama, mandiri dan tidak berpihak. Kelima, sifat ini adalah dasar karakter seorang pejabat Notaris, yaitu (Sinaga, 2019):

1. Amanah yaitu dapat dipercaya melaksanakan tugasnya yaitu melaksanakan perintah dari para pihak, orang yang menghendaki Notaris untuk menuangkan maksud dan keinginannya dalam suatu akta dan para pihak membubuhkan tanda tangannya pada akhir akta.

2. Jujur yaitu tak berbohong atau menutup nutupi segala sesuatunya.

3. Seksama yaitu berhati hati dan teliti dalam menyusun redaksi akta agar tak merugikan para pihak.

4. Mandiri yaitu ketika Notaris memutuskan sendiri akta yang dibuat itu berstruktur hukum yang tepat, serta dapat memberikan penyuluhan hukum kepada klien.

5. Tak berpihak yaitu notaris bersifat netral, tidak memihak pada satu pihak.

Keterkaitan antara sumpah jabatan dan rahasia jabatan ditulis sangat jelas sebagaimana tercantum dalam Pasal 16 ayat (1) huruf $f$ tentang rahasia jabatannya. Dalam sumpah jabatannya seorang notaris menyatakan dengan tegas bersumpah untuk menjaga kerahasiaan aktanya dan seluruh keterangan yang diperolehanya selama melaksanakan jabatannya. Menjaga sikap, tingkah laku dan menjalankan kewajiban sesuai dengan kode etik profesi, kehormatan, martabat dan tanggung jawab sebagai Notaris. Menjalankan kewajiban sesuai dengan kode etik profesi, kehormatan, martabat dan tanggung-jawab sebagai Notaris, menjaga kehormatan martabat profesi Notaris, termasuk tidak menjelekkan sesama kolega Notaris atau perang tarif. Akan 
merahasiakan isi akta dan keterangan yang diperoleh dalam pelaksanaan jabatan. Merahasiakan isi akta dan keterangan yang diperoleh, maksudnya Notaris harus mendengarkan keterangan dan keinginan klien sebelum menuangkannya dalam bentuk akta. Notaris berkewajiban untuk merahasiakan seluruh isi akta dan seluruh keterangan yang didengarnya.

Terkait dengan kewajiban seorang notaris untuk menjaga kerahasiaan aktanya serta yang mana juga dinyatakan dalam sumpah jabatan notaris maka: secara umum seorang notaris wajib untuk menjaga isi dan keterangan yang diperoleh selama pembuatan akta notaris kecuali diperintahkan lain oleh undang-undang bahwa notaris tidak wajib merahasiakan dan memberikan keterangan yang diperlukan berkaitan pembuatan akta tersebut. Karena itu notaris mempunyai hak ingkar yang hakiki (Prajitno, 2010). Notaris berhak untuk tidak menjawab pertanyaan hakim bila terjadi masalah atas akta notariil yang dibuatnya. Keterangan/kesaksian yang diberikan oleh Notaris adalah sesuai dengan yang dituangkannya dalam akta tersebut. Hak ini gugur apabila berhadapan dengan Undang-Undang tindak pidana korupsi (Pasal 16 UUJN). Tidak memberikan janji atau menjanjikan sesuatu kepada siapapun baik secara langsung atau tidak langsung dengan nama atau dalih apapun yaitu berkaitan dengan hal pemberian uang untuk pengangkatan di wilayah tertentu (Sinaga, 2019).

Hak ingkar ini semata-mata bukan diberikan kepada seseorang pribadi, namun untuk kepentingan umum atau kepentingan masyarakat. Hak ini mengesampingkan ketentuan dari KUHPerdata Pasal 1909 ayat (1) yaitu "Semua orang yang cakap untuk menjadi saksi, diharuskan memberikan kesaksian di muka Hakim". Kewajiban pelaporan Notaris sebagaimana dimaksud tersebut dilakukan sebagai upaya pencegahan dan pemberantasan TPPU, juga dimaksudkan untuk (Anggraeni, 2017):

1. Memberikan perlindungan hukum kepada Notaris apabila terdapat Transaksi Keuangan Mencurigakan (TKM) yang mana berdasarkan hasil riset PPATK diketahui bahwa beberapa profesi rentan digunakan jasanya oleh pelaku TPPU. Para pelaku kejahatan money laundering untuk menyembunyikan atau menyamarkan asalusul harta kekayaan yang merupakan hasil kejahatan dengan cara berlindung dibalik ketentuan kerahasiaan hubungan profesi notaris dengan pengguna jasa.

2. Kewajiban pelaporan oleh pelaku profesi tersebut telah diterapkan beberapa negara dan ternyata memliki dampak postitif terhadap pencegahan dan pemberantasan TPPU.

3. Untuk memberikan perlindungan hukum kepada Pihak Pelapor dalam hal ini para Notaris dari tuntutan hukum.

Sehingga jika masih ada pelaku TPPU yang memakai jasa notaris untuk mengaburkan usul asal dana yang berasal Tindak pidana. Notaris tidak dianggap menjadi fasilitator para pelaku TPPU pada rangka melakukan penyembunyian atau penyamaran atas usul, asal, lokasi, peruntukkan, pengalihan hak-hak, atau kepemilikan yang sebenarnya atas harta kekayaan yang diketahuinya atau patut diduganya hasil tindak pidana. Perlindungan hukum bagi profesi dapat disimpulkan sebagai berikut (Anggraeni, 2017): 
1. Pelindungan dari kriminalisasi tindak pidana pencucian uang sebagaimana diatur dalam Pasal 5 ayat (2) UU PPTPPU.

2. Pelindungan atas pelaksanaan kewajiban pelaporan oleh Pihak Pelapor dikecualikan dari ketentuan kerahasiaan yang berlaku bagi Pihak Pelapor yang bersangkutan sebagaimana dimaksud dalam Pasal 28 UU PPTPPU.

3. Pelindungan tuntutan pidana dan/atau gugatan perdata, kecuali terhadap unsur penyalahgunaan wewenang, dalam rangka pelaksanaan kewajiban pelaporan sebagaimana dimaksud dalam Pasal 29 UU PPTPPU.

4. Kewajiban merahasiakan Pihak Pelapor oleh pejabat dan pegawai PPATK, penyidik, penuntut umum, dan hakim sebagaimana dimaksud dalam Pasal 83 ayat (1) UU PPTPPU.

Hak ingkar dalam UUJN diatur lebih tegas dalam menjalankan kewajiban untuk memberikan keterangan sebagai saksi ataupun memberikan kesaksian atas akta yang dibuatnya tidak perlu diingkari tetapi harus melalui proses persetujuan dari Majelis Kehormatan Notaris. Yang artinya Notaris menjadi salah satu Profesi yang memiliki kewajiban melapor sebagaimana yang terdapat dalam Pasal 3 PP Nomor 43 Tahun 2015 untuk mencegah terjadinya Tindak Pidana Pencucian Uang tidaklah melanggar ketentuan yang terdapat dalam Undang-Undang Pasal 16 ayat (1) huruf f UUJN.

Berdasarkan teori kepastian hukum dan nilai yang ingin dicapai yaitu nilai keadilan dan kebahagiaan. Adanya kepastian hukum merupakan harapan bagi masyarakat luas. Karena dengan adanya kepastian hukum masyarakat akan tahu kejelasan akan hak dan kewajiban masing-masing. Tanpa adanya kepastian hukum maka orang tidak tahu apa yang harus diperbuat dan tidak mengetahui perbuatanya benar atau salah, dilarang atau tidak dilarang oleh hukum yang berlaku. Kepastian hukum ini dapat diwujudkan melalui penormaan yang baik dan jelas dalam suatu bentuk undang-undang agar jelas pula arah dan tujuan penerapanya. Sebagaimana yang menjadi tujuan atau harapan norma hukum yang mengaturnya.

Menurut Sudikno Mertukusumo, kepastian hukum adalah sebuah jaminan bahwa hukum itu dapat dijalankan dengan baik. Karena kepastian hukum sudah menjadi hal yang tidak dapat dipisahkan, tentu hal ini memang lebih diutamakan untuk norma hukum yang tertulis. Pada dasarnya kepastian sendiri merupakan tujuan utama dari terselenggaranya hukum. Kepastian hukum ini menjadi keteraturan masyarakat berkaitan erat dengan kepastian itu sendiri.

Dengan demikian, berdasarkan penjelasan diatas dapat dikatakan bahwa kewajiban notaris mengenali prinsip pengguna jasa dikarenakan Notaris menjadi salah satu Profesi yang memiliki kewajiban melapor sebagaimana yang terdapat dalam Pasal 3 PP Nomor 43 Tahun 2015 untuk mencegah terjadinya Tindak Pidana Pencucian Uang oleh korporasi tidaklah melanggar ketentuan Pasal 16 ayat (1) huruf f UUJN. Dengan begitu Notaris diberikan kebebasan melaporkan korporasi yang melakukan tindak pidana pencucian uang kepada pihak yang berwajib. Kewajiban pelaporan Notaris tersebut dilakukan untuk memberikan perlindungan hukum kepada Notaris apabila terdapat Transaksi Keuangan Mencurigakan (TKM), Sehingga jika masih ada pelaku 
TPPU yang memakai jasa notaris untuk mengaburkan asal usul dana yang berasal dari Tindak Pidana Pencucian Uang. Notaris tidak dianggap menjadi fasilitator para pelaku TPPU pada rangka melakukan penyembunyian atau penyamaran atas usul, asal, lokasi, peruntukkan, pengalihan hak-hak, atau kepemilikan yang sebenarnya atas harta kekayaan yang diketahuinya atau patut diduganya hasil tindak pidana. Membuka kerahasiaan akta yang dibuat dalam hal digunakan untuk pelaporan Tindak Pidana Pencucian Uang yang sebagaimana yang tercantum dalam PP Nomor 43 Tahun 2015 sudah memenuhi nilai keadilan dan kebahagiaan. Berdasarkan penjelasan tersebut apabila dikaitkan dengan teori kepastian hukum maka adanya ketentuan dalam PP Nomor 43 Tahun 2015 yang menyatakan bahwa Notaris menjadi salah satu profesi yang wajib melapor tindak pidana pencucian uang merupakan wujud kepastian hukum yang diberikan terhadap Notaris untuk memberikan perlindungan hukum terhadap notaris yang menerapkan Prinsip Mengenali Pengguna Jasa.

\section{Kesimpulan}

Kewajiban notaris mengenali pengguna jasa dalam upaya pencegahan tindak pidana pencucian uang oleh korporasi tidak bertentangan dengan Pasal 16 ayat (1) huruf f Undang-Undang Republik Indonesian Nomor 2 Tahun 2014 tentang Perubahan atas Undang-Undang Nomor 30 Tahun 2004 tentang Jabatan Notaris. Dengan begitu Notaris diberikan kebebasan melaporkan korporasi yang melakukan tindak pidana pencucian uang kepada pihak yang berwajib. Kewajiban pelaporan Notaris tersebut dilakukan untuk memberikan perlindungan hukum kepada Notaris apabila terdapat Transaksi Keuangan Mencurigakan (TKM), Sehingga jika masih ada pelaku TPPU yang memakai jasa notaris untuk mengaburkan usul asal dana yang berasal Tindak pidana, Notaris tidak dipercaya menjadi fasilitator para pelaku TPPU pada rangka melakukan penyembunyian atau penyamaran atas usul, asal, lokasi, peruntukkan, pengalihan hakhak, atau kepemilikan yang sebenarnya atas harta kekayaan yang diketahuinya atau patut diduganya hasil tindak pidana. Membuka kerahasiaan akta yang dibuat dalam hal digunakan untuk pelaporan Tindak Pidana Pencucian Uang yang sebagaimana yang tercantum dalam PP Nomor 43 Tahun 2015 sudah memenuhi nilai keadilan dan kebahagiaan.

Berdasarkan hasil kajian tersebut penulis memberikan saran, antara lain: Saran kepada pemerintah hendaknya melakukan pembaharuan atas Undang-Undang Jabatan Notaris dan Undang-undang Pencegahan dan pemberantasan tindak pidana pencucian uang mengenai kewajiban pelaporan transaksi keuangan mencurigakan. 
Ismail, Ermanto Fahamsyah, I Gede Widhiana Suarda

\section{BIBLIOGRAFI}

Adjie, Habib. (2008). Hukum Notaris Indonesia: Tafsir Tematik Terhadap UU No. 30

Tahun 2004 Tentang Jabatan Notaris. Refika Aditama. Google Scholar

Adrian Sutedi, Sh. (2008). Tindak pidana pencucian uang. Citra Aditya Bakti. Google Scholar

Amrullah, M A, \& Korporasi, Perkembangan Kejahatan. (2018). Dampak dan Permasalahan Hukumnya. Jakarta: Kencana Pernada Media Group. Google Scholar

Amrullah, M Arief. (2020). Tindak pidana pencucian uang dalam perspektif kejahatan terorganisasi: pencegahan dan pemberantasannya. Kencana. Google Scholar

Anggraeni, Elisabet Yunaeti. (2017). Pengantar sistem informasi. Penerbit Andi. Google Scholar

Ibrahim, Johnny. (2006). Teori dan metodologi penelitian hukum normatif. Malang: Bayumedia Publishing, 57. Google Scholar

Kohar, Abdul. (1983). Notaris Dalam Praktek Hukum. Alumni. Google Scholar

Muhammad Ridha Haykal Amal, Arie Kartika. (2021). Beneficial Ownership Arrangements in Saving Loan Cooperative as a Preventive Attempt to the Crime of Money Laundering. European Journal of Social Sciences Studies. Vol 6. Issue 2. Google Scholar

Muhtar Hadi Wibowo. (2018). Corporate Responsibility in Money Laundering Crime (Perspective Criminal Law Policy in Crime of Corruption in Indonesia), Journal of Indonesian Legal Studies. Vol 3. Issue 02. Google Scholar

Nasution, Eva Syahfitri. (2015). Pertanggungjawaban Pidana Korporasi dalam Tindak Pidana Pencucian Uang. Jurnal Mercatoria, 8(2), 132-144. Google Scholar

Peraturan Pemerintah Republik Indonesia. (2015). Pihak Pelapor Dalam Pencegahan dan Pemberantasan Tindak Pidana Pencucian Uang.

Permatasari, Mudiana. (2017). Penerapan Prinsip Mengenali Pengguna Jasa Oleh Notaris Sebagai Pihak Pelapor Terhadap Transaksi Keuangan Yang Mencurigakan Dalam Tindak Pidana Pencucian Uang. Universitas Gadjah Mada. Google Scholar

Poesoko, Herowati. (2010). Diktat Mata Kuliah Metode Penulisan dan Penelitian Hukum. Jember: Fakultas Hukum Universitas Jember. Google Scholar

Prajitno, A. A. Andi. (2010). Apa dan Siapa Notaris di Indonesia. Cet. Pertama, Putra Media Nusantara, Surabaya. Google Scholar 
Sari, Anggri Puspita, Pelu, Muhammad Faisal A. R., Dewi, Idah Kusuma, Ismail, Marthinus, Siregar, Robert Tua, Mistriani, Nina, Marit, Elisabeth Lenny, Killa, Maklon Felipus, Purba, Bonaraja, \& Lifchatullaillah, Endang. (2020). Ekonomi Kreatif. Yayasan Kita Menulis. Google Scholar

Sinaga, Sahat Hmt. (2019). Notaris dan badan hukum Indonesia. Jala Permata Aksara. Google Scholar

Tarigan, Yudha Pratama. (2021). Perlindungan Hukum Terhadap Pihak Pembeli Tanah Berdasarkan Perjanjian Jual Beli Tanah Yang Penjualnya Wanprestasi (Studi Putusan Nomor: 50/Pdt. G/2018/PN Bnj). Kumpulan Karya Ilmiah Mahasiswa Fakultas Sosial Sains, 2(02). Google Scholar

Undang-undang Jabatan Notaris No 2 tahun 2014. (2014). Perubahan atas Undangundang Nomor 30 Tahun 2004 Tentang Jabatan Notaris.

Yanuarsari, Maya Wira. (2018). Penerapan Doktrin Diminished Responsibility Terhadap Bank Dalam Melaksanakan Prinsip Know Your Costumers Terkait Transaksi Keuangan Yang Mencurigakan. Fairness and Justice: Jurnal Ilmiah Ilmu Hukum, 16(2).Google Scholar

\section{Copyright holder:}

Ismail, Ermanto Fahamsyah, I Gede Widhiana Suarda (2021)

\section{First publication right:}

Syntax Idea

This article is licensed under: 